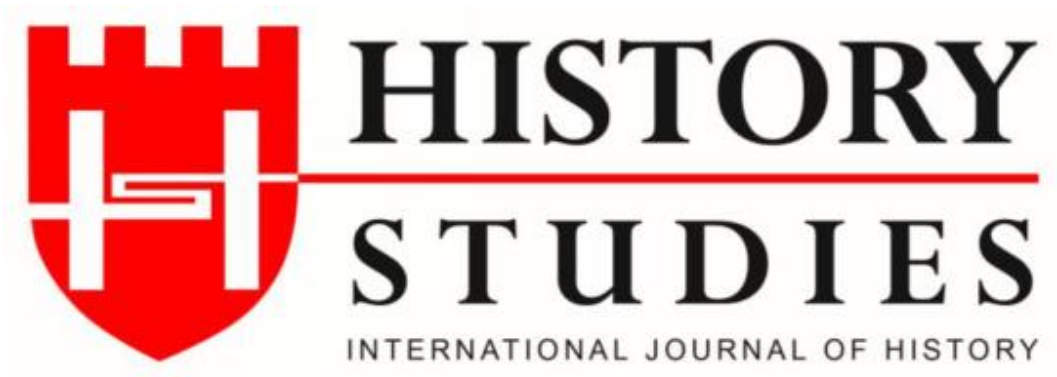

ISSN: 13094173 (Online) 1309 - 4688 (Print)

Volume 10 Issue 9, p. 157-173, December 2018

DOI Number: 10.9737/hist.2018.680

\title{
1845 Tarihli Malkara Kazası Müslüman Defterine Göre Malkara Kazası'nın Demografik Yapısı
}

Demographic Structure of Malkara District According to the Muslim Registry of Malkara District Dated 1845

Burçin IŞIM

(ORCID: 0000-0003-2636-1077)

\begin{abstract}
Öz: Bu çalışmada 1844 Tarihli Malkara Müslüman Nüfus Defteri'nin değerlendirmesi yapılmış olup defterde kayıtll mahallelerin ve köylerin isimleri, nüfusları, hane saylları, iskân eden şahısların isimleri ve yaşları tespit edilmiş, bu tespitler üzerinden Müslüman erkek nüfusunun isimlerinin analizi, hane başına düşen ortalama kişi sayısı, meslekleri ve kayıt altına alınan kişilerin fiziki özellikleri tasnif edilmeye çalıșılmıştır.
\end{abstract}

HISTORY

STUDIES

Volume 10

Issue 9

December

2018

Anahtar Kelimler: Malkara, Nüfus sayımı, Osmanlı Devleti

\begin{abstract}
In this work, the evaluation of the muslim registry of Malkara district (1845) has beeen done, and also the names and overall population of the villages, locals and their age have beenn identified. Through this, analysis of the names of the men of muslim population, average number of people per household, their jobs and known physical apperances have been classified.
\end{abstract}

Keywords: Malkara, Population Cencus, Ottoman Empire

\section{Giriş}

Nüfus, Arapça bir kelime olan nefs kelimesinin çoğuludur. "Ruh, can, hayat" anlamına gelir ve daha çok, bir coğrafyada yaşayan insanları ifade etmektedir. ${ }^{1}$

Nüfus sayımları, bir toplumu meydana getiren fertlerin sayı, cinsiyet, yaş, meslek, dil ve din durumlarını ortaya koyduğundan toplumların sosyolojik ve ekonomik tarihlerini inceleyecek araştırmacılar için oldukça önemlidir. Osmanlı Arşivi'nde asıl kayıtlara ait 7700 adet nüfus defteri vardır. Bu sayı yoklama defterleri ile 41.000'ini bulmaktadır. ${ }^{2}$

Osmanlı Devleti'nin ilk dönemlerinden itibaren nüfus ve arazi tahrirleri denilen sayım faaliyetleri olmuştur. Bununla devlet askerî gücünü ve gelirlerini tespit etmede önemli bir mesafe almıştır. ${ }^{3}$ Yazma, kaydetme ve deftere geçirme anlamına gelen tahrir kelimesi terim olarak Osmanlı maliye teşkilatında vergileri ve bu vergileri verenlerin ismen tespiti için değişik dönemlerde, farklı şehirlerde gerçekleştirilen sayımları ve bu sayımların kaydedildiği

\footnotetext{
${ }^{1}$ Nebi Bozkurt, "Nüfus", Türkiye Diyanet Vakfi İslam Ansiklopedisi (TDVİA), C.33, Ankara 2007, s.293.

${ }^{2}$ Mehmet Artunay-Ali Lafçı, Osmanlı Arşiv Belgelerinde Zara II Zara/Koçgiri Nüfus Defterleri, Kitabevi Yayınevi, İstanbul 2013, s.16.

${ }^{3}$ Süleyman Demirci-Kâzım Kartal, "Osmanlı Nüfus Defterleri'nin Tarih Yazımındaki Yeri: 1835 Tarihli Trabzon Vilayeti Maçuka/MAÇKA Kazası Müslim Nüfus Defteri Örneği”, History Studies İnternational Journal Of History, Volume 6, Issue 3, April 2014, s.120.
} 
defterleri ifade etmektedir. Osmanlı Devleti'nde ilk tahririn ne zaman yapıldı bilinmemektedir.

Osmanlı Devleti'nde 15. yüzyıldan itibaren ele geçirilen bölgelerin bütün iktisadi ve beşerî güç unsurlarını tespit etmek amacıyla yapılan tahrirler, konusu ve içeriğine göre mufassal, evkaf ve icmal defterleri olarak; yıllarına göre defter-i köhne, defter-i atik ve defter-i cedid olarak tasnif edilmiştir. Bu klasik tahrir usulü 16 . yüzyılın sonlarına kadar devam etmiştir. $\mathrm{Bu}$ tarihten sonra cizye için cizye muhasebe defterleri, tımar için tımar yoklama defterleri ve avarız için avarız defterleri tutulmaya başlanmıştır. ${ }^{4}$

II. Mahmud'un kurduğu yeni ordu için asker tedariki gündeme gelince erkek nüfusunu tespit etmek amacıyla geniş çaplı bir nüfus sayımı yapılmış olup bu sayımlarda erkek nüfus yaş ve dış görünüşüne göre tespit edilmiş, altı ayda bir nüfustaki ölüm, doğum, göç gibi değişiklikler yazılmıştır. Bu gelişme ileride modern nüfus sayımlarının başlangıcı olmuştur.

1246 (1831) yılı II. Mahmud zamanında yapılan ilk genel nüfus sayımının amacı askere alınacak nüfusu ve cizye alınabilecek gayrimüslim nüfusu tespit etmekti. ${ }^{6}$ Ayrıca çoğu yerlerde sayılanların meslekleri de kayıt altına alındı. ${ }^{7}$ Misır, Arabistan, Arnavutluk Bosna ve Güneydoğu Anadolu 1831 sayımından hariç tutuldu ve sayım aşağı yukarı en önemli on eyalette gerçekleşti. ${ }^{8}$

1831 yılında yapılan nüfus sayımı Osmanlı Devleti'nin toprak yazımı vesilesi olmadan yapılan nüfus sayımı kabul edilir. Ayrıca 1831 sayımı, öncesi ve sonrasında çıkarılan nizamnameler ile ülke dâhilinde merkezî bir nüfus kayıt sisteminin kurulması ve nüfus değişikliklerinin düzenli olarak takip edilmesi yönünden önemlidir. ${ }^{9} 1831$ sayımının ardından yapılan nüfus sayımlarını değerlendirmek için Ceride Nezareti kuruldu. Böylece Eyalet ve bazı sancaklara nüfus nazırı, kazalara nüfus memuru, nahiyelere de mukayyid isimli memurlar görevlendirildi. ${ }^{10}$

Mevcut durumda uzun süren askerlik, yorgun düşmüş Müslümanların endişelerini gidermek ve sayımı yapılan kişilerin doğru cevap vermelerini sağlayabilmek maksadıyla sayımı yapacak memurlar saygın dinî sınıfa mensup kadılar ve ulema arasından atanmışlardı. Yaklaşık 85 üst düzey memurun hizmetine verilen çok sayıdaki kâtiple birlikte sahaya gönderilmesi 1831 sayımına verilen önemi açık bir şekilde göstermektedir. ${ }^{11}$

Sayımı yapan memurlara sayımın nasıl yapılacağına dair yazılı bir talimat verilmemiş, yapılacak sayımla ilgili şifahen bilgi verilmiştir. ${ }^{12}$ Memurların Müslüman nüfusunu kayıt

\footnotetext{
${ }^{4}$ Salih Akyel-Kamil Özdemir, “1835 Tarihli Nüfus Defterine Göre Tirebolu'da Gayrimüslim Nüfus Yapısı”, Türkiyat Araştırmaları Dergisi, S.37, s.166.

${ }^{5}$ Mehmet Öz, "Tahrir" TDVIA, C.39, Ankara 2007, s.425.

${ }^{6}$ Osmanlı İdaresi'nde Kıbrıs, (Nüfusu-Arazi Dağılımı ve Türk Vakıfları), T.C. Başbakanlık Devlet Arşivleri Genel Müdürlüğü Osmanlı Arşivi Daire Başkanlığı, Yayın No: 43, Ankara 2000, s.46.

${ }_{7}$ Musa Çadırcı, "1830 Genel Sayımına Göre Ankara Şehir Merkezi Nüfusu Üzerinde Bir Araştırma”, Osmanlı Araştırmaları I, İstanbul 1980, s.110.

${ }^{8}$ Musa Şaşmaz, "The Ottoman Censuses And The Registration Systems in The Nineteenth and Early Twentieth Centuries”, Ankara Üniversitesi Osmanlı Tarihi Araştırma ve Uygulama Merkezi Dergisi, S. 6 s. 290.

${ }^{9}$ Salih Akyel,-Savaş Sertel, “Osmanlı Nüfus Defterleri'nin Tarih Yazımındaki Yeri: 1840 Tarihli Çarsancak Kazası Gayrimüslim Nüfus Defteri Örneği,” Journal of History and Future, C.1, S.1, Aral1k 2015, s.1.

10 İbrahim Serbestoğlu, “19. Yüzyılda Osmanlı Devleti'nde Nüfus Algısının Değişimi ve Nüfusu Arttırma Çabasında Müfettişlerin Rolü”, Balıkesir Üniversitesi Sosyal Bilimler Enstitüsü Dergisi, 17/31, Haziran 2014 s. 260 .

${ }^{11}$ Kemal H. Karpat, Osmanlı Nüfusu (1830-1914) Demografik ve Sosyal Özellikleri, Tarih Vakfı Yurt Yayınları, İstanbul 2003, s.58.

${ }^{12}$ Osmanlı İdaresinde Klbrls, 54. Karpat, a.g.e., 58.
} 
ederken aynı esasa göre hareket etmemeleri belki de ellerine yazılı bir talimat verilmemiş olmasından dolayıdır. ${ }^{13}$ Bu sebeple sayımı yapılan bölgelerde kimi memurlar yaşa göre kimi sakal bıyık durumuna göre ayrım yapmış, kimi yerlerde de askerliğe elverişli olup olmadıklarına göre hareket etmişlerdir. ${ }^{14}$

Tanzimat ile birlikte Osmanlı Devleti'nin çeşitli kademelerinde başlayan yenileşme hareketleri, mahallî idarelerde de birtakım değişiklikleri beraberinde getirdi. Mahallelerde doğan, ölen ve gelip giden kişilerin takibi görevi imamlardan alındı ve muhtarlara verildi. gayrimüslimlerde ise papazlardan alınıp kocabaşılara verildi. ${ }^{15}$

1839'dan itibaren nüfus işlerini takip etmek için kazalarda nüfus memuru ve mukayyid adıyla memurlar görevlendirildi. Bu memurların görevi, sorumluluk sahasındaki doğum ve ölüm olaylarını takip etmek, aylık cetvellerini tutmak ve bunları İstanbul'a göndermekti. ${ }^{16}$

1831 sayımından sonra ülke genelinde 1844 yılında tekrar bir sayım yapıldı. Bu sayımın amac1 "Redif-i Asâkir-i Mansure" adıyla kurulan yeni orduya alınabilecek nüfus potansiyelini tespit etmekti. ${ }^{17} \mathrm{Bu}$ sayım 1831 yılında yapılan sayımın tecrübelerinden yararlanılarak daha ayrintıli yapild $1 .{ }^{18}$

Araştırmamıza esas olan 4114 numaralı Malkara Müslüman Nüfus Defteri de 1845 tarihli defter olup toplam 124 varaktır.

\section{1-) Defter'in Tanıtımı}

1845 Tarih ve 4114 numaralı Malkara Müslüman Nüfus Defteri 20x55.5 cm boyutunda olup ciltsiz ve ebrusuzdur. Bu defterde, sadece Malkara merkezinde ve köylerinde iskân eden Müslüman erkek nüfus kayda geçirilmiştir. Nüfus defteri yazılırken öncelikle mahalle ismi yazılmış; mahalle ismini, hane numarası ve hane altında yaşayan isimler takip etmiştir. Kayıt altına alınan şahısların, ilk önce fiziki özellikleri tarif edilmiştir. Kısa, orta, uzunca ve uzun şeklinde boy tarifi yapılmış, arkasından bıyık ve sakalının rengi kara, kumral, sarı, kır, ak vb. olacak şekilde düzenlenmiştir. Fiziki özellikleri belirtildikten sonra -varsa- mesleği yazılmış, hemen arkasından da adı ve baba adı yazılmıştır. Şahsın tüm bu özelliklerinin altına "sinn" yani yaşı yazılmıştır.

4114 numaralı Malkara Müslüman Nüfusu Defteri “Tekfurdağı mülhakatından Malkara kazasının yerlü ehl-i İslâmının sinn ve eşkal ve zanaat ve hane ve numaralarını mübeyyin tahrir-i nüfûs defteridir." ${ }^{\prime 19}$ açıklamasıyla başlamıştır. Defterin kaydını tutanların, defterde isimleri yazılı şahısların yanındaki açıklamalara istinaden, Şakir Efendi bin Mehmed ${ }^{20}$ ve Muytab Bekir Efendi bin İsmail ${ }^{21}$ olduğu anlaşılmaktadır.

\footnotetext{
${ }^{13}$ Nedim İpek-Rıza Karagöz-Cihat Uslucan, Canik Sancağı Samsun Kazası'nın Nüfus Yapısı (1834-1845) Canik Belediyesi Kültür Yayınları, Kültür Yayınları No: 9, Samsun 2016, s. 3.

${ }^{14}$ Karpat, a.g.e., s. 58; Osmanlı Idaresinde Kıbrls, s. 54.

${ }^{15}$ Osmanlı İdaresinde Kıbris, s. 47.

${ }_{17}^{16}$ a.g.e.s.48.

${ }^{17}$ age., 61.

${ }^{18}$ Hümeyra Özer, Lâdik Nüfus Defteri (1846) Tarihli) Transkripsiyon ve Değerlendirme, T.C. (İstanbul Üniversitesi Sosyal Bilimler Enstitüsü Yüksek Lisans Tezi), İstanbul 2015, s.10.

${ }_{19}$ BOA (Başbakanlık Osmanlı Arşivi) Edirne Vilayeti, Tekfurdağı, Gelibolu Sancağı, Malkara Kazası Müslim Defteri, Nüfus Defteri, (BOA, NFS.d.), 4114, s.1.

${ }^{20}$ BOA NFS.d., 4114, s.8, Şakir Efendi bin Mehmed'in yanında açıklama olarak: "Bâ-berât-1 şerif-i âlişan mukayyid-i defter-i nüfus" yazmaktadır.

${ }^{21}$ BOA NFS.d., 4114, s.29, Muytab Bekir Efendi bin İsmail'in yanında açılama olarak: "Bâ-ferman-1 âlişan nazır-1 defter-i nüfus" yazmaktadır.
} 
Osmanlıca rika hattında tutulan bu defter siyah mürekkep kullanılarak yazılmıştır. Ancak deftere kaydedilen bazı şahısların üzerine kırmızı mürekkep yazısı ile notlar düşülmüştür. Bu kırmızı notlarda müftü, imam, hatib, müezzin gibi dinî görevleri icra eden, kaza müdürü ${ }^{22}$, mahkeme kâtibi ${ }^{23}$, zıraat müdürü ${ }^{24}$, muhtar gibi devlet görevlilerinin yazıldığı görülmüştür. Ayrıca askerlik görevini yapanlar, askerliğini bitirip gelenler, başka bir yere gidenler veya başka bir yerden gelenlerinde durum açıklamalarının kırmızı mürekkeple yazıldığı görüldüğü gibi topal, çolak gibi özür durumları olanlarında mevcut hallerinin kırımızı yazı ile yazıldığı tespit edilmiştir. Hane içindeki sıra numaraları da kırmızı mürekkeple yazılmıştır. Deftere yazılan şahıslar bir önceki yazılan şahıs ile aynı niteliğe sahip ise "bu dahi" şeklinde not edilmiştir.

İncelediğimiz deftere göre, nüfus sayımına, Cami-i Atik Mahallesi'nden başlandığını görmekteyiz. $\mathrm{Bu}$ mahalleye verilen önemin, müftünün burada oturmuş olmasından dolayı olduğu düşünülebilir. ${ }^{25}$ Malkara nüfus defterinde kaydedilen ilk kişi Malkara Müftüsü, Müftü Mehmed Tayyib Efendi bin Mehmed Efendidir. ${ }^{26}$

Malkara'da görev yapan din görevlilerin yanına, hangi camide görevli oldukları yazılmış olup buna göre Malkara'da yedi adet cami ismi tespit edilmiştir. Bunlar, Gazi Ömer Bey Cami, Gazi Süleyman Paşa Cami, Hacerzade Cami, Turhan Bey Cami, Gazi Kasab Mahmud Bey Cami, Rumzade Cami, Ahmed Kethüda Cami'dir. ${ }^{27}$

Malkara ve köylerinden başka bölgelere muallimlik mesleğini yapmaya gidenler ${ }^{28}$ ve başka bir bölgede öğrenci ${ }^{29}$ olanlar da deftere kaydedilmiştir. Yine bu kayıtlardan anlaşılmaktadır ki Malkara'da Turhan Bey Cami-i Şerif adlı bir medrese vardır. ${ }^{30}$

\footnotetext{
${ }^{22}$ Kaza Müdürü, Kazandan Mehmed Tayyib Efendi bin Osmandır. BOA NFS.d., 4114, s.14.

${ }^{23}$ Mahkeme Katibi, Kazandan Salih Efendi bin Hacı Hüseyindir. BOA NFS.d., 4114, s.14; Malkaralı olup başka bir yerde kâtiplik yapanlarda defterde yazılmıştır: Kaya Bey Mahallesi 3. haneden "Ketebeden Ali Efendi bin Mehmed Efendi tavattun suretiyle der-i aliyede katib olduğu Sene [12]54.”, BOA NFS.d., 4114, s. 35.

${ }^{24}$ Zıraat Müdürü: Hacı Ahmed Ağa bin Ahmed'in oğlu Ketebeden Hüseyin Efendi'dir. BOA NFS.d., 4114, s.44.

${ }^{25}$ Buna benzer bir durumun Denizli' de de olduğunu görmekteyiz. Bkz. Denizli-1831 Nüfus Sayımı Prosopografisi, Mehmet Şeker, Nilgün Çevik, İzmir 2007, s.7.

${ }^{26}$ BOA NFS.d., 4114, s.1.

${ }^{27}$ Gazi Ömer Bey Cami için bkz. BOA NFS.d., 4114, s.1, 13, 37; Gazi Süleyman Paşa Cami için bkz. BOA NFS.d. 4114, s.1; Hacerzade Cami için bkz. BOA NFS.d., 4114, s.2; Turhan Bey Cami için bkz. BOA NFS.d., 4114, s.10, 119; Gazi Kasab Mahmud Bey Cami için, bkz. BOA NFS.d., 4114, s.31, 35 ; Rumzade Cami için bkz. BOA NFS.d., 4114, s.31; Ahmed Kethüda Cami için bkz. BOA NFS.d., 4114, s.35.

${ }^{28}$ Hacı Hasan Mahallesi 2. haneden Mustafa bin Halil'in oğlu Halil: "Hayrabolu kazası Umur Bey karyesinde muallim-i sıbyân. Sene [12]57.”, BOA NFS.d., 4114, s.10; Tekke Mahallesi'nde 14. haneden Ömer Efendi bin Mehmed: "Hayrabolu kazası Tatarlı karyesinde muallim-i sıbyân. Sene [12]45.”, BOA NFS.d., 4114, s.39; Tahta Mescid Mahallesi 3. haneden: "Münla Mehmed bin İbrahim Muallim-i Sîbyan olup İnecik kazası Dedecik karyesine gitmiş. Sene [12]54.”, BOA NFS.d., 4114, s.49; Harala karyesi 12. haneden Münla Mehmed bin Halil "Cisr-i Ergene kazası Harmanlı karyesinde muallim-i sıbyân. Sene [12]57.”,BOA NFS.d., 4114, s.59; Yabancı Ehl-i İslam Defteri Maksudlu karyesi 1. sırada: "Molla Mustafa bin Hüseyin, muallim-i sıbyân olub Cisr-i Ergene kazasından gelmiştir. Sene [12]53.", BOA NFS.d., 4144, s.120.

${ }^{29}$ Defterde tespit edilen ilk öğrenci: Fatma Sultan Mahallesi 1. haneden "Hacı İbrahim Efendi bin Mustafa'nın diğer oğlu Molla Ahmed, Dersaadet’te Sultan Selim Medresesine gitmiş. Sene [12]58.”, BOA NFS.d., 4114, s.45; İkinci öğrenci Danişmed karyesi 2. haneden "Rençber Süleyman bin Mehmed oğlu talebeden Ali Molla, Keşan Medresesine gitmiş. Sene [12]53.”, BOA NFS.d., 4114, s.74; Üçüncü öğrenci Deveci Yenicesi karyesi 10. haneden: "Rençber Mehmed bin Süleyman oğlu talebeden İbrahim Efendi, talebeden olup Dersaadet'te Sultan Mehmed Medresesinde mukim. Sene [12]57.”, BOA NFS.d., 4114, s.92; Dördüncü öğrenci İbribey karyesi 4. haneden: "Rençber Ali bin Hasan oğlu Mehmed, Tekfurdağı'na okumaya gitmiş. Sene [12]60.”, BOA NFS.d., 4114, s.97; Beşinci öğrenci Kırıkali karyesi 1. haneden: "Rençber İsmail bin Ali, karındaşı İbrahim, Hayrabolu kazası Evren Bey karyesinde okumakta olduğu sene [12]59.”, BOA NFS.d., 4114, s.98; Altıncı öğrencimiz Küçük Hıdır karyesi 12. haneden: "İmam Raşit Efendi ibn Seyid oğlu Arif Münla, der-i aliye'de talebe olduğu", BOA NFS.d., 4114 s.110.
} 
Deftere yazılan kişilerin özür durumları ve hastalıkları not edilmiştir. Malkara ve köylerinde on kişi topal, sekiz kişi yekçeşm, sekiz kişi illetli, yedi kişi çolak, beş kişi âmâ, üç kişi meczub, iki kişi alil, iki kişi mariz, bir kişi kanbur, bir kişi mariz-i masru, bir kişi eğri boyun, bir kişi sağ gözü iskat, bir kişi sağ gözünde ak var, bir kişi iki gözünde misafir var, bir kişinin ise sağ gözü arızalı ${ }^{31}$ şeklinde özür durumları yazılmıştır.

1844 yılı sayımı askerî amaçlı yapılmış bir sayımdır ve bu amaca uygun olarak askerliğe elverişli olamayacak durumda olanların yanına, yukarıda belirtilen özür durumları yazılmıştır. Yine askerlik görevini yapanlar, askerden gelenler veya görevleri sırasındaki rütbeler gibi bilgiler tek tek şahısların isimlerinin yanına not edilmiştir. Farklı ifadeler ile anlatılan askerlik görevi ile ilk bilgi Cami-i Atik Mahallesi 11. hanedeki Kahveci Mustafa bin Ahmed'in oğlu Mehmed ile ilgili tutulan bilgidir. Bu bilgi şu şekildedir: "Asâkir-i Nizamiye-i Şahanede.",32 Toplamda 15 kişi bu cümle ile belirtilmiştir. ${ }^{33}$ Toplam $28 \mathrm{kez}$ ile en fazla ifade edilen cümle ise askerliğini denizci olarak yapan kişileri belirtmek için kullanılan "Asâkir-i Bahriye-i Şahanede" ${ }^{34}$ olmuştur.

Hâlen askerde olan rütbeliler de deftere yazılmıştır. Buna göre: Rabia Hatun Mahallesi'nden Said Efendi bin Mehmed'in sağ kol ağası olduğu ${ }^{35}$, Beşir Fakı Mahallesi'nden Haşim bin Mehmed'in Mühendishane'de mülazım olduğu ${ }^{36}$ anlaşılmaktadır. Emekli olup gelenlerin ne kadar maaş aldıkları ve nereden emekli oldukları da belirtilmiştir. Defterde ilk tespit edilen kişi Helvacı Ömer bin Ebubekir'in oğlu Mehmed'dir. Bu kişinin yanına düşülen not şu şekildedir: "Asâkir-i Bahriye hâcelerinden olup bâ-tezkire-i tersane-i amire şehri yüz kuruş maaşla mütekaid" 37 ikinci tespit edilen Tekye Mahallesi 19. haneden Mustafa bin Mustafa'dır: "Bâ-berat-1 şerif-i alişan asâkir-i nizamiyeden şehri on üç kuruş kırk akçe maaş ile mütekaid" "38, üçüncü tespit edilen kişi ise İ̆̆timur karyesinden Rençber Eyüp Bin Hüseyin'dir: “Asâkir-i Nizamiye-i Şahane neferatından olub bâ-berat-1 alişan şehriye on kuruş maaş ile mütekaid. Sene [12]58"39

\footnotetext{
${ }^{30}$ Medresedeki öğrenci Yabancı Ehl-i İslam Defteri, Malkara 11. sırada kaydedilmiştir: "Talebeden Mehmed Efendi bin Hasan, İskeçe'den olup Turhan Bey Cami-i Şerif Medresesinde mukîm olduğu sene [12]60", BOA NFS.d., 4114, s.120; II. Murat ümerasından Gazi Turhan Bey Malkara'da bir cami, medrese, imaret vakfetmiş, bu vakıfların masraflarını temin etmek içinde Malkara'da birkaç dükkân, değirmen ve kervansaray inşa ettirmişti. Bkz. İbrahim Sezgin, "Malkara Şehri (1475-1601)", İlmî Araştırmalar II, İstanbul 1996, s. 123.

${ }^{31}$ Topal için bkz. BOA NFS.d., 4114, s.1, 11, 22, 24, 33, 47, 59, 65, 76, 80; Yekçeşm için bkz. BOA NFS.d., 4114, s.17[2], 18, 30, 40, 45, 73, 75; İlletli için bkz. BOA NFS.d., 4114, s.19, 23[2], 33, 61, 65, 100[2]; Çolak için bkz. BOA NFS.d., 4114, s.5, 13, 16, 40, 75, 109, 121; Âmâ için bkz. BOA NFS.d., 4114, s.5, 10, 45, 61, 90; Meczup için bkz. BOA NFS.d., 4114, s.22, 85, 121; Alil için bkz. BOA NFS.d., 4114, s.20, 29; Mariz için bkz. BOA NFS.d., 4114, s.31, 66; Kanbur için bkz. BOA NFS.d., 4114, s.16; Mariz-i Masru için bkz. BOA NFS.d., 4114, s.40; Eğri Boyun için Bkz. BOA NFS.d., 4114, s.79; Sağ gözü iskat için bkz. BOA NFS.d., 4114, s.49; Sağ gözünde ak var için bkz. BOA NFS.d., 4114, s.59; İki gözünde misafir var için bkz. BOA NFS.d., 4114, s.86; Sağ gözü arızalı için bkz. BOA NFS.d., 4114, s.66.

${ }^{32}$ BOA NFS.d., 4114, s.,

${ }^{33}$ BOA NFS.d., 4114, s.2, 5, 11, 35, 37, 51, 56[2], 59, 66, 67, 69, 90, 110[2].

${ }^{34}$ BOA NFS.d., 4114, s.11, 26, 45[2], 53[2], 65, 66, 69, 70[2], 72[2], 75, 76[2], 77, 94, 95, 101, 104, 110[2], 112, 114[2], 115, 117; Diğer askerlik durumları şu ifadelerle anlatılmıştır. "Asâkir-i Bahriye-i Nizamiyede", bkz. BOA NFS.d., 4114, s.10; iki kişi "asâkir" ifadesi ile yazılmıştır. Bkz. BOA NFS.d., 4114, s.27, 113; Bir kişi içinde “Asâkir-i Nizamiyede" ifadesi yazılmıştır. Bkz. BOA NFS.d., 4114, s.113; Defter tutulduktan sonra askere alınan kişi sayısı altıdır. Bu kişiler ise şu cümle ile anlatılmıştır: "vürûdiye silk-i Asâkir-i Bahriye" Bkz. BOA NFS.d., 4114 , s. $9,27,53,61,85,112$.

${ }^{35}$ BOA NFS.d., 4114, s.28.

${ }^{36}$ BOA NFS.d., 4114. s.33.

${ }^{37}$ BOA NFS.d., 4114, s.16,

${ }^{38}$ BOA NFS.d., 4114, s.40.

${ }^{39}$ BOA NFS.d., 4114, s.105.
} 
Rütbeli olarak askerlik hizmetini bitirip gelenlerden defterde ilk tespit edilen kişi Hacı İsrail Mahallesi 10. haneden debbağ esnafından Mehmed bin Mustafa'dır: "Asâkir-i Nizamiyei Sol Kol ağalarından olup bâ-tezkire-i ser asakir-i asâkiriden bila-maaş muhrec" 40

Askerlik hizmetinden gelenlerde çeşitli sinıflandırmaya tabi tutulmuştur. $\mathrm{Bu}$ sınıflandırmaların başında askerlik görevinden izinsiz ve tezkiresiz gelenler gelmektedir. İzinsiz veya tezkiresiz gelenler en çok şu ifade ile anlatılmıştır: "Asâkir-i Bahriyeden bilamezun gelmiştir" ${ }^{41}$ Tezkere alan ancak maaşsız gelenler ise en çok : Bâ-tezkire-i hazret-i kapudani asâkir-i bahriyeden bila-maaş muhrec ${ }^{42}$. ifadesi ile kaydedilmiştir. Firar edip gelenler de ise: "Asâkir-i Bahriyeden firar edip gelmiş" edilmiştir.

\section{2-) Malkara'nın Mahalleleri, Köyleri ve Nüfusu}

1845 tarihinde yapılan sayımda Edirne Vilayeti Gelibolu Livasına bağlı bir kaza olan Malkara'da 27 mahalle, 29 köy ve 14 çiftlik vardır. ${ }^{44}$

1845 y1lı nüfus defterine göre Malkara'daki Müslüman erkek nüfusu merkezde 722 'dir. Köylerinde ve çiftliklerindeki erkek nüfus 962 olup merkez ve köylerindeki toplam erkek nüfusu 1684'tür. Kadın nüfusunun da erkek nüfusu kadar olduğunu düşünürsek Malkara'nın köyleri ile birlikte muhtemel toplam Müslüman nüfusu 3368'dir. Toplam erkek nüfusun \%42.87'si Malkara merkezinde, \%57.13'ü ise kırsal kesimde yaşamaktadır.

Malkara'da en kalabalık mahalle Cami-i Atik Mahallesi'dir. En az nüfus ise sadece iki kişinin oturduğu Fatma Sultan Mahallesi'dir. Elli ve ellinin üzerinde nüfusa sahip üç mahalle vardır. Bunlar Cami-i Atik, Kaya Bey, ve Hacı Yakub Mahalleleri'dir. On ve altında nüfusa sahip mahalle sayısı ise beştir. Bu mahalleler de Hacı Mehmed, Hüseyin Ağa, Alaca Hacı, Hacı Yunus ve en az nüfusa sahip Fatma Sultan Mahallesi'dir.

\footnotetext{
${ }^{40}$ BOA NFS.d., 4114, s.7; Diğer askerlik hizmetinden rütbeli olarak gelenler ise şu şekilde tespit edilmiştir: Hac1 Mehmed Mahallesi 6. haneden, nalband esnafından Mustafa Ağa bin Ali: "Bâ-tezkire-i hazret-i ser askeri asakir-i nizamiye-i şahane yüzbaşılığından bila-maaş-1 muhreç.”, BOA NFS.d., 4114, s.8; İshak Fakı Mahallesi 2. haneden Derviş Osman bin Hüseyin'in oğlu Sadullah: "Bâ-tezkire-i hazret-i kapudanî asakir-i bahriye-i şahane çavuşluğundan bila-maaş muhrec Sene [12]60.”, BOA NFS.d., 4114, s.24; Tekye Mahallesi 10. haneden İsmail bin İbrahim: Asâkir-i Bahriye onbaşılarından olub bâ-tezkire-i tersane-i asâkirlere bila-maaş silk-i asâkiriyeden muhrec. Sene [12]54.”, BOA NFS.d., 4114, s.39; Yabanc1 Ehl-i Müslim Defteri Develi Karyesi 2. sıradan Hizmetkâr İbrahim bin Hüseyin, "Bâ-tezkire-i hazret-i ser askeri asâkir-i nizamiye-i şahane çavuşluğundan bila-maaş muhrec. Sene [12]59, BOA NFS.d., 4114, s.122.

${ }^{41}$ BOA NFS.d., 4114, s.6, 16, 19, 25, 27, 37, 100; Diğer ifadelerimiz ise şu şekildedir: "Asâkir- Bahriye-i Şahaneden bila-mezun gelmiștir", BOA NFS.d., 4114, s.6; "Asâkir-i Nizamiyeden bila-mezun gelmiştir.", BOA NFS.d., 4114, s.45; "Asâkir-i Nizamiye-i Şahaneden bila-mezun bila-tezkiresiz gelmiştir.", BOA NFS.d., 4114, s.39; "Asâkir-i Bahriyeden bila-tezkire ve bila-mezun gelmiştir.", BOA NFS.d., 4114, s.42.

${ }^{42}$ BOA NFS.d., 4114, s.46[2], 47, 80; Diğer ifadelerimiz ise şu şekildedir: "Mekteb-i Ulum-1 Bahriye-i Şahaneden bâ-tezkire-i hazret-i kapudanî bila-maaş muhrec.", BOA NFS.d., 4114, s.43; "Asâkir-i Nizamiye-i Şahaneden olup bâ-tezkire-i hazret-i ser askeri silk-i asâkiriden bila-maaş muhrec", BOA NFS.d., 4114, s.64; "Asâkir-i Bahriye-i Şahaneden olup bâ-tezkire-i hazret-i kapudanî silk-i asâkiriden bila-maaş muhrec", BOA NFS.d., 4114, s.66; "Bâtezkire-i hazret-i ser askeri Asâkir-i Nizamiye-i Şahaneden bila-maaş muhrec", BOA NFS.d., 4114, s.65; "Asâkir-i Nizamiye-i Şahaneden bâ-tezkire-i hazret-i ser askeri bila-maaş muhreçBOA NFS.d., 4114, s.67; "Asâkir-i Nizamiye-i Şahane neferatından bâ-tezkire-i hazret-i ser askeri silk-i asakiriden bila-maaş muhrec" BOA NFS.d., 4114, s.106; "Bâ-tezkire-i hazret-i ser askeri nizamiyeden bila-maaş muhrec" BOA NFS.d., 4114, s.76.

${ }^{43}$ BOA NFS.d., 4114, s.59, 61,73, 106, 109; Diğer ifadelerimiz ise şu şekildedir: "Asâkir-i Bahriyeden bila-mezun firar edip gelmiş", BOA NFS.d., 4114, s.45; "Asâkir-i Nizamiye-i Bahriyeden bila-mezun firar gelmiştir." BOA NFS.d., 4114, s.46; "Asâkir-i Bahriye-i Nizamiyeden firar edip gelmiş.", BOA NFS.d., 4114, s.53. 64, 109; "Asâkir-i Nizamiyeden olup bila-tezkire firar edip gelmiş", BOA NFS.d., 4114, s.56; "Asâkir-i Bahriye-i Şahaneden firar edip gelmiş", BOA NFS.d., 4114, s.64, 92, 105[2]; "Asâkir-i Nizamiye-i Şahane'den firaren gelmiş", BOA NFS.d., 4114, s.90.

${ }^{44}$ BOA NFS.d., 4114.
} 
Malkara'nın en kalabalık köyü 79 nüfusla Balaban köyüdür. En az nüfus ise üç kişilik nüfusu ile Bulgur köyüdür. Sadece dört köyün nüfusu elli ve elli kişinin üzerindedir. Bunlar Balaban, Çavuş, İğtimur ve Kalaycı'dır. Çiftlik nüfuslarının hepsi on kişinin altındadır.

Malkara merkezde 316, köy ve çiftliklerde 343, toplamda 659 hane vardır. En kalabalık nüfusa sahip Cami- Atik Mahallesi'nin 24 hane ile en fazla ikinci hane sayısına sahip olduğunu görmekteyiz. En fazla hane ise 28 hane ile Kaya Bey Mahallesi'ndedir. Yine en düşük nüfusa sahip Fatma Sultan Mahallesi'nde ise sadece bir hane mevcuttur. Malkara merkezde on ve üzeri nüfusa sahip mahalleler de hane başına düşen kişi sayısı ile en yüksek yoğunluğa sahip mahalle, hane başına düşen 2.88 ortalama ile Hacı Halil Mahallesi, en düşük yoğunluğa sahip mahalle ise 1.83 ortalama ile Serraç Gazi Mahallesi'dir.

1845 y1lı nüfus defterinde Malkara'ya bağlı köy ve çiftliklerde 342 hane sayısı görülmektedir. 34 hane ile Balaban en fazla haneye sahip birinci köy iken, İğtimur 21 hane ile ikinci sıradadır. Dördüncü sırada ise Çavuşköy gelmektedir. Sadece bir hane ile en az hane Bulgur köyündedir. Bulgur köyünü iki hane ile Kuyucu köyü takip etmektedir. Kuyucu köyünden sonra dört hane ile İshakça, Sasan ve Kadıköyü gelmektedir. Malkara'nın köylerinde on ve onun üzerinde nüfusa sahip köylerde hane başına düşen kişi sayısı ortalaması 5 ile Kuyucu köyü birinci sırada olup Alaybey 3.71 ortalama ile ikinci sıradadır. Çavuşköy 2.84 ortalama ile üçüncüdür. En az yoğun köy ise 1.69 ortalama ile Obalar köyüdür.

Malkara ve köylerinde bulunan toplam 659 Hanenin \%47.95'i Malkara merkezinde $\% 52.05$ 'i ise köy ve çiftliklerdedir.

Tablo 1: Malkara ve Köylerindeki Hane Sayısı, Nüfus ve Nüfusun Haneye Oranı ${ }^{45}$

\begin{tabular}{|c|c|c|c|c|}
\hline $\begin{array}{c}\text { Sura } \\
\text { No }\end{array}$ & Mahalle-Köy Adı & Hane sayısı & Nüfusu & $\begin{array}{c}\text { Hane Başına } \\
\text { Düşen Kişi } \\
\text { Sayısı }\end{array}$ \\
\hline $\mathbf{1}$ & Cami-i Atik Mahallesi & 24 & 59 & 2.45 \\
\hline $\mathbf{2}$ & Hacı Memi & 10 & 22 & 2.20 \\
\hline $\mathbf{3}$ & Hacı İsrail & 13 & 29 & 2.23 \\
\hline $\mathbf{4}$ & Hacı Mehmed & 6 & 9 & 1.50 \\
\hline $\mathbf{5}$ & Hacı Mahmud & 6 & 16 & 2.66 \\
\hline $\mathbf{6}$ & Hacı Hasan & 20 & 43 & 2.15 \\
\hline $\mathbf{7}$ & Hacı Halil & 9 & 26 & 2.88 \\
\hline $\mathbf{8}$ & Hüseyin Ağa & 3 & 8 & 2.66 \\
\hline $\mathbf{9}$ & Hacı Sinan & 17 & 45 & 2.64 \\
\hline $\mathbf{1 0}$ & Hacı Yakub & 21 & 52 & 2.47 \\
\hline $\mathbf{1 1}$ & Hacı Evhad & 21 & 47 & 2.28 \\
\hline $\mathbf{1 2}$ & İshakfakı & 17 & 34 & 2.00 \\
\hline $\mathbf{1 3}$ & Hacı İbrahim & 8 & 18 & 2.25 \\
\hline $\mathbf{1 4}$ & Rabia Hatun & 6 & 13 & 2.16 \\
\hline
\end{tabular}

${ }^{45}$ Tabloya, 4114 sayılı defterdeki yabancı ehl-i Müslim nüfusunun hane sayısı belirtilmediği için yabancı ehl-i Müslim nüfus oran hesaplanmasına eklenmemiştir. Tablo 4114 no.lu defterdeki sıraya göre düzenlenmiştir. 
1845 Tarihli Malkara Kazası Müslüman Defterine Göre Malkara Kazası'nın Demografik Yapısı

\begin{tabular}{|c|c|c|c|c|}
\hline 15 & Mezid Fakı & 10 & 20 & 2.00 \\
\hline 16 & Ahi Ana & 8 & 17 & 2.12 \\
\hline 17 & Beşir Fak1 & 13 & 31 & 2.38 \\
\hline 18 & Kaya Bey & 28 & 56 & 2.00 \\
\hline 19 & Tekye & 20 & 43 & 2.15 \\
\hline 20 & Nalband Hizir & 12 & 23 & 1.91 \\
\hline 21 & Saray & 6 & 13 & 2.16 \\
\hline 22 & Fatma Sultan & 16 & 40 & 2.50 \\
\hline 23 & Alaca Hacı & 3 & 7 & 2.33 \\
\hline 24 & Serrac Gazi & 6 & 11 & 1.83 \\
\hline 25 & Tahta Mescid & 10 & 21 & 2.10 \\
\hline 26 & Hacı Yunus & 2 & 6 & 3.00 \\
\hline 27 & Fatma Hatun & 1 & 2 & 2.00 \\
\hline 28 & Yabancı Ehl-i Müslim & - & 11 & - \\
\hline \multicolumn{2}{|c|}{$\begin{array}{c}\text { Malkara Merkez Toplam Hane } \\
\text { Sayısı ve Toplam Nüfusu }\end{array}$} & 316 & 711 & 2.25 \\
\hline \multicolumn{2}{|c|}{$\begin{array}{c}\text { Malkara'nın Yabancı Nüfusu ile } \\
\text { Birlikte Toplam Nüfusu }\end{array}$} & - & 722 & \\
\hline
\end{tabular}

Tablo 2: Malkara'nın Köylerindeki Hane Sayısı, Nüfus ve Nüfusun Haneye Oranı

\begin{tabular}{|c|c|c|c|c|}
\hline $\begin{array}{c}\text { Sıra } \\
\text { No }\end{array}$ & Mahalle-Köy Adı & Hane sayısı & Nüfusu & $\begin{array}{c}\text { Hane Başına } \\
\text { Düşen kişi Sayısı }\end{array}$ \\
\hline $\mathbf{2}$ & İbrice Çiftliği & 1 & 1 & 1.00 \\
\hline $\mathbf{3}$ & Tatar & 6 & 12 & 2.00 \\
\hline $\mathbf{4}$ & Timurcili & 10 & 30 & 3.00 \\
\hline $\mathbf{5}$ & Timurcili Çiftlĭgi & 1 & 4 & 4.00 \\
\hline $\mathbf{6}$ & Karahisar Çiftliği & 1 & 1 & 1.00 \\
\hline $\mathbf{7}$ & Harala & 14 & 38 & 2.71 \\
\hline $\mathbf{8}$ & Maksudlu & 21 & 48 & 2.28 \\
\hline $\mathbf{9}$ & Balaban & 34 & 79 & 2.32 \\
\hline $\mathbf{1 0}$ & Karaağaç & 17 & 48 & 2.82 \\
\hline $\mathbf{1 1}$ & Karasatı & 11 & 24 & 2.18 \\
\hline $\mathbf{1 2}$ & Danişmend & 12 & 32 & 2.66 \\
\hline $\mathbf{1 3}$ & Yayla & 13 & 31 & 2.38 \\
\hline $\mathbf{1 4}$ & Çiftlik-i İmam & 1 & 2 & 2.00 \\
\hline
\end{tabular}


Burçin IŞIM

\begin{tabular}{|c|c|c|c|c|}
\hline 15 & $\mathrm{Kad}_{1}$ & 4 & 8 & 2.00 \\
\hline 16 & Haliç & 10 & 23 & 2.30 \\
\hline 17 & Obalar & 13 & 22 & 1.69 \\
\hline 18 & Kalaycı & 18 & 50 & 2.77 \\
\hline 19 & Bulgur & 1 & 3 & 3.00 \\
\hline 20 & Sasan & 4 & 9 & 2.25 \\
\hline 21 & Ahievren & 13 & 39 & 3.00 \\
\hline 22 & Deveci Yenicesi & 12 & 32 & 2.66 \\
\hline 23 & Develi & 12 & 31 & 2.58 \\
\hline 24 & İbribey & 5 & 12 & 2.40 \\
\hline 25 & Kırıkali & 7 & 19 & 2.71 \\
\hline 26 & Kermiyan & 16 & 39 & 2.43 \\
\hline 27 & Yörük & 7 & 17 & 2.42 \\
\hline 28 & Çiftlik-i Yörük Yenicesi & 2 & 5 & 2.50 \\
\hline 29 & İğtimur & 21 & 57 & 2.71 \\
\hline 30 & Çiftlik- i Sarıca Paşa & 1 & 4 & 4.00 \\
\hline 31 & Kuyucu & 2 & 10 & 5.00 \\
\hline 32 & Küçük Hıdır & 12 & 42 & 3.50 \\
\hline 33 & Alaybey & 7 & 26 & 3.71 \\
\hline 34 & Çavuş & 19 & 54 & 2.84 \\
\hline 34 & İshakça & 4 & 9 & 2.25 \\
\hline \multicolumn{2}{|c|}{$\begin{array}{l}\text { Malkara Köyleri Toplam Hane } \\
\text { Sayısı ve Toplam Nüfusu }\end{array}$} & 343 & 896 & 2.61 \\
\hline \multicolumn{2}{|c|}{$\begin{array}{c}\text { Malkara Merkez ve Köyleri } \\
\text { Toplam Hane Sayısı ve Toplam } \\
\text { Nüfusu }\end{array}$} & 659 & 1607 & 2.43 \\
\hline \multicolumn{2}{|c|}{$\begin{array}{c}\text { Malkara'da Yabancı Ehl-i } \\
\text { Müslim }\end{array}$} & & 11 & \\
\hline \multicolumn{2}{|c|}{$\begin{array}{c}\text { Malkara'nın Köy ve } \\
\text { Çiftliklerindeki Yabancı Ehl-i } \\
\text { Müslim }\end{array}$} & & 66 & \\
\hline \multicolumn{2}{|c|}{$\begin{array}{c}\text { Malkara Merkez, Köy ve Çiftlik } \\
\text { Toplam Nüfusu }\end{array}$} & & 1684 & \\
\hline
\end{tabular}


Tablo 3: Malkara Merkez, Köy ve Çiftliklerdeki Yabacı Ehl-i Müslim Nüfusu

\begin{tabular}{|c|c|c|c|c|c|}
\hline $\begin{array}{c}\text { Sira } \\
\text { No }\end{array}$ & Yer & Nüfus & $\begin{array}{l}\text { Sira } \\
\text { No }\end{array}$ & Yer & Nüfus \\
\hline 1 & Malkara & 11 & 13 & Karye-i Ahievren & 2 \\
\hline 2 & İbrice An-Çiflik Ahmed Ağa & 2 & 14 & Karye-i Develi & 3 \\
\hline 3 & Karye-i Tatar & 2 & 15 & Karye-i İbribey & 3 \\
\hline 4 & Karye-i Harala & 1 & 16 & Karye-i Kırıkali & 9 \\
\hline 5 & Karye-i Maksudlu & 1 & 17 & Karye-i Yörük & 3 \\
\hline 6 & Karye-i Karağaç & 2 & 18 & Karye-i İ̆ğtimur & 4 \\
\hline 7 & $\begin{array}{l}\text { Çiftlik-i Aylani Kısrak Eşref } \\
\text { Ağa }\end{array}$ & 4 & 19 & Çiftlik-i Sarıca Paşa & 4 \\
\hline 8 & $\begin{array}{c}\text { Karye-i Yayla An-Çitlik Agob } \\
\text { Çorbacı }\end{array}$ & 2 & 20 & Çiftlik-i Softça & 2 \\
\hline 9 & Karye-i Kadı & 1 & 21 & Çiftlik-i Kuyucu & 2 \\
\hline 10 & $\begin{array}{l}\text { Karye-i Kalaycı An-Çiftlik } \\
\text { Lâtif Efendi }\end{array}$ & 4 & 22 & Karye-i Mesmud & 1 \\
\hline 11 & Çiftlik-i Çalış & 6 & 23 & $\begin{array}{c}\text { Küçük Hıdır An-Çiflik Fevzi } \\
\text { Efendi }\end{array}$ & 6 \\
\hline 12 & Karye-i Sasan & 1 & 24 & Çiftlik-i Taşkın & 1 \\
\hline \multicolumn{5}{|r|}{ Toplam Nüfus } & 77 \\
\hline
\end{tabular}

\section{3-) Malkara ve Köylerinde Meslekler}

1845 yılı defterlerinde Malkara'da 299 kişinin isimlerinden önce veya şahsın tüm bilgilerinin yazıldığı alanın üzerine, icra etmekte oldukları meslekleri belirtilmiştir ve incelenen defterde 37 çeşit meslek tespit edilmiştir. Devlet kademelerinde çalışan kaza müdürü, ziraat müdürü, mahkeme kâtibi, muhtar yada dinî görevleri icra etmekte olan müftü, imam, hatib, müezzin gibi mesleklere sahip şahısların üzerine kırmızı yazı ile ne iş yaptıklarını belirtir not düşülmüştür. Malkara'da en çok icra edilen meslek rençberlik ${ }^{46}$ yani çiftçiliktir. 38 kişi ile debbağl $1 \mathrm{k}^{47}$ meslek dağılımında 2. sırada yer alırken 3. sırayı çapacılık almıştır. Muhtar, muytab ${ }^{48}$, berber ve helvacılık mesleğini yapan kişi sayısı da 10 'un üzerindedir.

\footnotetext{
${ }^{46}$ Zahmetli işler gören gündelikçi, ırgat, çiftçi. Adem Kandemir-Fikri Okut, Osmanlıca Türkçe Sözlük, İstanbul 1997, Erdem Yayınlar1, s.501.

${ }^{47}$ Bazı araştırmalar debbağlık ve deri işçiliğinin Anadolu'da ilk gelişen meslek olabileceğini göstermekte olup debbağlığı başlatan kişinin, kendisi de bir debbağ olan aynı zamanda Ahî teşkilatının kurucusu olan Ahî Evren olduğunu göstermektedir. Debbağlar Ahîlik geleneği sayesinde esnaf locaları üzerinde etkili bir nüfusa sahiptiler. 18. yy.ın ikinci yarısında mesleklerinin zirvesine çıkmışlardı ve diğer esnaftan zenginlik açısından üstün idiler. Bkz. Zeki, Tekin, "Türklerde Dericilik", TDVIA, C.39, Ankara 2007, s. 176; Malkara ilçesinde debbağlık mesleğinin önemli bir yeri olduğunu görmekteyiz. 4114 no.lu nüfus defterinden beş yıl önce yapılmış olan 1840 yılı Keşan nüfus defterini incelediğimizde Malkara'ya en yakın ilçe olan ve aşağı yukarı nüfusları birbirine yakın olan Keşan'da 13 kişi Debbağlık mesleğini icra etmektedir ki bunların ikisi kalfadır. Bu sayılardan anlaşılmaktadır ki Malkara'da Keşan'a göre debbağ sayısı 3 kat fazladır. Bkz. BOA NFS.d., 4096.

${ }^{48}$ Kıl dokuyan, kıldan eşya yapan. Bkz. Ferit Develioğlu, Osmanlıca-Türkçe Ansiklopedik Sözlük, Aydın Kitabevi Yayınları, Ankara 1993, s. 1109.
} 
Meslek dağılımına bakıldığında mesleği belirtilenlerin \%34.44'ü rençber, \%12.70'i ise debbağdır. Tarım ve hayvancıllk ile doğrudan bağlı meslek grupları meslek dağılımının \%45.48'ini oluşturmaktadır. Dinî görevleri icra edenlerin oranı ise \%5.68'dir.

Tablo 4: Malkara Merkez Meslekler

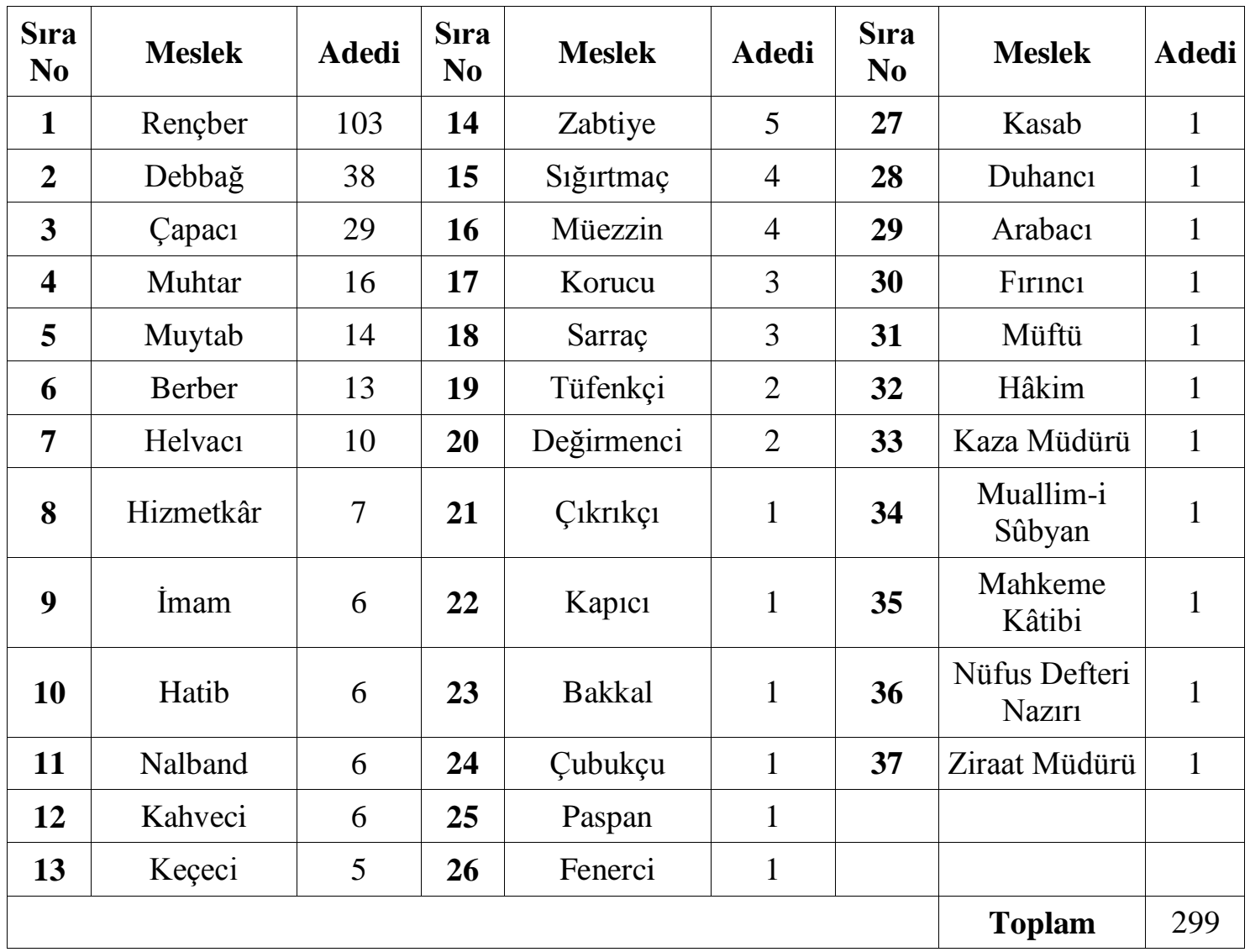

Malkara'nın köy ve çiftliklerinde 16 farklı meslek çeşidi tespit edilmiştir. Toplamda 484 şahsın mesleği yazılmıştır. Malkara merkezden deveci, çoban, odacı, $\operatorname{attar}^{49}$, celep $^{50}$ ve çavdarcı olmak üzere 6 farklı meslek görülmektedir. Deveci mesleği en çok Obalar köyünde görülmekte olup köylerdeki 12 devecinin 11'i Obalar köyünde yerleşiktir. Malkara'nın köylerinde tespit edilen meslekler arasında en önemli yeri çiftçilik almaktadır. Çiftçilikle iştigal olan şahıslar meslek dağılımında \%75.20 ile zirvede yer almaktadır. Tarım ve hayvancılık meslek dağılımında toplamda $\% 83.05$ ile en büyük paya sahiptir.

Tablo 5: Malkara'nın Köylerinde Meslekler

\begin{tabular}{|c|c|c|c|c|c|c|c|c|}
\hline $\begin{array}{c}\text { Sıra } \\
\text { No }\end{array}$ & Meslek & Adedi & $\begin{array}{c}\text { Sıra } \\
\text { No }\end{array}$ & Meslek & Adedi & $\begin{array}{c}\text { Sıra } \\
\text { No }\end{array}$ & Meslek & Adedi \\
\hline $\mathbf{1}$ & Rençber & 364 & $\mathbf{7}$ & Berber & 6 & $\mathbf{1 3}$ & Attar & 1 \\
\hline $\mathbf{2}$ & Hizmetkâr & 34 & $\mathbf{8}$ & Çoban & 5 & $\mathbf{1 4}$ & Celeb & 1 \\
\hline
\end{tabular}

${ }^{49}$ Güzel kokulu ruhlar ve yağlar vesaire satan adam, ecza-yı tıbbiye vesaire satan adam, mahalle aralarında bazı baharatla iğne iplik satan dükkâncı. Bkz. Şemseddin Sami, Kamûs-ı Turkî, (Latin Harfleriyle), Haz.: Raşit Gündoğdu-Niyazi Adıgüzel-Ebul Faruk Önal, İdeal Kültür, İstanbul 2012, s.1109.

${ }^{50}$ Kesilecek hayvanat ve alel'husus koyun sürüsü celp ile kasaplara satan tacir. Bkz. s.377. 
1845 Tarihli Malkara Kazası Müslüman Defterine Göre Malkara Kazası'nın Demografik Yapısı

\begin{tabular}{|c|c|c|c|c|c|c|c|c|}
\hline $\mathbf{3}$ & Muhtar & 30 & $\mathbf{9}$ & Çapacı & 5 & $\mathbf{1 5}$ & $\begin{array}{c}\text { Muallim-i } \\
\text { Sûbyan }\end{array}$ & 1 \\
\hline $\mathbf{4}$ & Sı̆̆ırtmaç & 12 & $\mathbf{1 0}$ & Korucu & 2 & $\mathbf{1 6}$ & Çavdarc1 & 1 \\
\hline $\mathbf{5}$ & Deveci & 12 & $\mathbf{1 1}$ & Odacı & 1 & & & \\
\hline $\mathbf{6}$ & İmam & 8 & $\mathbf{1 2}$ & Hatib & 1 & & & \\
\hline
\end{tabular}

\section{4-) Malkara ve Köylerinde İsimler}

Malkara nüfus defterinde 108 farklı isim vardır. Malkara merkez ve köylerinde en çok kullanılan isim Mehmed'tir. Merkezde 203, köylerde ise 198 kez Mehmed ismine rastlanmış olup bu isim, Malkara merkezde kullanılan baba-oğul isimleri arasında \%17.85, köylerde ise \%13.55 gibi bir orana sahiptir. Malkara'da sırasıyla Mehmed, Ahmed ve Hüseyin en çok kullanılan isimler arasında yer alırken köylerinde ise sırasıyla Mehmed, Ahmed ve Mustafa en çok kullanılan üç isim olmuştur. Malkara ve köylerinde yüzden fazla şahsa verilen isimler arasında yer alan Mehmed, Ahmed, Mustafa, Hüseyin, Ali, Hasan, İbrahim, İsmail ve Osman isimleri toplamda $1815 \mathrm{kez}$ olarak kaydedilmiştir. Bu isimlerin genele oranı \%69.86 olup neredeyse her 10 kişiden 7'si bu sayılan isimler ile anılmıştır.

Tablo 6: Malkara ve Köylerinde Kullanılan İsimler

\begin{tabular}{|c|c|c|c|c|c|c|c|c|c|}
\hline No & İsim & 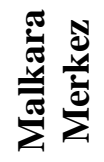 & 莺 & $\frac{\Xi}{\frac{\Xi}{a}}$ & No & İsim & 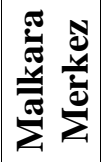 & 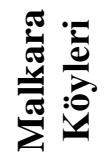 & $\frac{\Xi}{\frac{\pi}{\sigma}}$ \\
\hline 1 & Mehmed & 203 & 198 & 401 & 55 & Bilâl & 2 & 1 & 3 \\
\hline 2 & Ahmed & 138 & 134 & 272 & 56 & Musa & 2 & 1 & 3 \\
\hline 3 & Mustafa & 94 & 122 & 216 & 57 & İlyas & - & 3 & 3 \\
\hline 4 & Hüseyin & 102 & 110 & 211 & 58 & Riza & 2 & 1 & 3 \\
\hline 5 & Ali & 81 & 126 & 207 & 59 & Lâtif & 1 & 2 & 3 \\
\hline 6 & Hasan & 62 & 88 & 150 & 60 & Eyüb & - & 3 & 3 \\
\hline 7 & İbrahim & 46 & 74 & 120 & 61 & Yahya & 1 & 2 & 3 \\
\hline 8 & İsmail & 51 & 69 & 120 & 62 & Numan & 1 & 1 & 2 \\
\hline 9 & Osman & 57 & 61 & 118 & 63 & Cafer & 1 & 1 & 2 \\
\hline 10 & Halil & 24 & 61 & 85 & 64 & Vahab & 2 & - & 2 \\
\hline 11 & Süleyman & 25 & 49 & 74 & 65 & Hamza & - & 2 & 2 \\
\hline 12 & Ömer & 29 & 33 & 62 & 66 & Rifat & 1 & 1 & 2 \\
\hline 13 & Salih & 20 & 37 & 57 & 67 & Rasim & 1 & 1 & 2 \\
\hline 14 & Abdullah & 21 & 23 & 44 & 68 & Esad & 1 & 1 & 2 \\
\hline 15 & Tahir & 19 & 17 & 36 & 69 & Abdülfettah & 1 & 1 & 2 \\
\hline 16 & Emin & 8 & 15 & 23 & 70 & Bektaş & 2 & - & 2 \\
\hline
\end{tabular}


Burçin IŞIM

\begin{tabular}{|c|c|c|c|c|c|c|c|c|c|}
\hline 17 & Mahmud & 6 & 14 & 20 & 71 & Sunullah & 2 & - & 2 \\
\hline 18 & Feyzullah & 6 & 13 & 19 & 72 & Beşir & - & 2 & 2 \\
\hline 19 & Şakir & 7 & 11 & 18 & 73 & Halid & 1 & 1 & 2 \\
\hline 20 & Yakub & 3 & 13 & 16 & 74 & Fettah & - & 2 & 2 \\
\hline 21 & Recep & 7 & 8 & 15 & 75 & Muhtar & 1 & 1 & 2 \\
\hline 22 & Arif & 7 & 8 & 15 & 76 & İzzet & - & 2 & 2 \\
\hline 23 & Yusuf & 5 & 10 & 15 & 77 & Mercan & 1 & - & 1 \\
\hline 24 & Bekir & 5 & 9 & 14 & 78 & Akif & 1 & - & 1 \\
\hline 25 & Said & 11 & 1 & 12 & 79 & Eşref & 1 & - & 1 \\
\hline 26 & Salim & 7 & 5 & 12 & 80 & Raan & 1 & - & 1 \\
\hline 27 & Memiş & 3 & 7 & 10 & 81 & Saim & 1 & - & 1 \\
\hline 28 & İbiş & 5 & 5 & 10 & 82 & Mecdi & 1 & - & 1 \\
\hline 29 & Emrullah & 4 & 5 & 9 & 83 & Hüsnü & 1 & - & 1 \\
\hline 30 & Edhem & 1 & 7 & 8 & 84 & İslâm & 1 & - & 1 \\
\hline 31 & Sadık & 4 & 4 & 8 & 85 & Abdülbaki & 1 & - & 1 \\
\hline 32 & Ebubekir & 6 & 1 & 7 & 86 & Haşim & 1 & - & 1 \\
\hline 33 & Selim & 1 & 6 & 7 & 87 & Pehlivan & 1 & - & 1 \\
\hline 34 & Raşid & 1 & 6 & 7 & 88 & Vehbi & 1 & - & 1 \\
\hline 35 & Yunus & - & 7 & 7 & 89 & Kabil & 1 & - & 1 \\
\hline 36 & Kadir & 2 & 5 & 7 & 90 & Cemaleddin & - & 1 & 1 \\
\hline 37 & Feyzi & 4 & 2 & 6 & 91 & Nuri & - & 1 & 1 \\
\hline 38 & Mestan & 3 & 3 & 6 & 92 & Muttalib & - & 1 & 1 \\
\hline 39 & Veli & - & 6 & 6 & 93 & Seyfi & - & 1 & 1 \\
\hline 40 & Şaban & 1 & 4 & 5 & 94 & Zeynel & - & 1 & 1 \\
\hline 41 & Necib & 3 & 2 & 5 & 95 & Kerim & - & 1 & 1 \\
\hline 42 & İdris & - & 5 & 5 & 96 & Vahib & - & 1 & 1 \\
\hline 43 & Nuh & 2 & 3 & 5 & 97 & Vasif & - & 1 & 1 \\
\hline 44 & Rüstem & 2 & 3 & 5 & 98 & Hamid & - & 1 & 1 \\
\hline 45 & Tayyib & 2 & 2 & 4 & 99 & Ruşan & - & 1 & 1 \\
\hline 46 & Veysel & 1 & 3 & 4 & 100 & Kadri & - & 1 & 1 \\
\hline 47 & Lütfullah & 2 & 2 & 4 & 101 & Seyfullah & - & 1 & 1 \\
\hline 48 & Şerif & 1 & 3 & 4 & 102 & Abdüllâtif & - & 1 & 1 \\
\hline 49 & Sadullah & 1 & 3 & 4 & 103 & Niyazi & - & 1 & 1 \\
\hline 50 & Hizır & - & 4 & 4 & 104 & Ragib & - & 1 & 1 \\
\hline
\end{tabular}


1845 Tarihli Malkara Kazası Müslüman Defterine Göre Malkara Kazası́nın Demografik Yapısı

\begin{tabular}{|c|c|c|c|c|c|c|c|c|c|}
\hline 51 & Hurşid & - & 4 & 4 & 105 & Barik & - & 1 & 1 \\
\hline 52 & İdris & 4 & - & 4 & 106 & Abdülmalik & - & 1 & 1 \\
\hline 53 & Mistık & 3 & - & 3 & 107 & Ferhad & - & 1 & 1 \\
\hline 54 & Şükrü & 2 & 1 & 3 & 108 & Durmuş & - & 1 & 1 \\
\hline \multicolumn{9}{|c|}{ Malkara Merkezi Toplamı } & 1137 \\
\hline \multicolumn{9}{|c|}{ Malkara Köyleri Toplamı } & 1461 \\
\hline \multicolumn{9}{|c|}{ Genel Toplam } & 2598 \\
\hline
\end{tabular}

\section{5-) Malkara ve Köylerinde Yaşayanların Fiziksel Özellikleri}

Nüfus defterinde yetişkinlerin hepsi boy ölçüsü ile tarif edilmiştir. Çocuklar ise boy tarifinde yer almamıştır. Tarif, kısa boylu, orta boylu, uzunca boylu ve uzun boylu olmak üzere 4 sınıfla tasniflendirilmiş ancak boy uzunluklarının neye göre tasnif edildiği belirtilmemiştir. Malkara merkezinde 434 kişi boy tarifi ile kaydedilirken köylerde bu sayı 629 olarak tespit edilmiştir. Malkara'da 269 kişi ile en çok orta boy tarifi yapılmıştır. Köylerde de yine en çok orta boy tarifini 358 kişi ile görmekteyiz. Malkara'da kısa boylular \%12.67, orta boylular $\% 61.98$, uzunca boylular \%4.60, uzun boylular \%20.73'lük bir orana sahiptir. Köylerinde ise bu oran, kisa boylular \%15.10, orta boylular \%56.94, uzunca boylular \%5.08, uzun boylular $\% 22.98$ 'dir.

Tablo 7: Malkara ve Köylerinde İskân Edenlerin Boy Uzunluklarına Göre Tasnifi

\begin{tabular}{|l|c|c|c|c|}
\hline \multicolumn{1}{|c|}{ Yer } & Kisa boylu & Orta boylu & Uzunca Boylu & Uzun Boylu \\
\hline Malkara Merkezi & 55 & 269 & 20 & 90 \\
\hline Malkara Köyleri & 95 & 358 & 32 & 144 \\
\hline
\end{tabular}

Nüfus defterine kaydedilen şahısların boy durumu yazıldıktan sonra sakal ya da bıyık tarifi yapılmıştır. Bıyık tarifi defterde beş şekilde izah edilmiştir. Bıyı̆̆ı ve sakalı henüz çıkmamış kişiler "şabb-1 emred" ${ }^{51}$ ", yeni yeni bıyıkları çıkanlar ter bıyıklı şeklinde tarif edilirken bu iki tarif dışında kalanlar bıyıklarının rengine göre kara, kumral ve sarı bıyıklı olarak tarif edilmiştir. Malkara'da en fazla 62 kişi ile "kumral bıyıklı" ifadesi kullanılırken köylerinde 123 kiși ile "sarı bıyıklı" ifadesi en çok kullanılan ifade olmuştur. Malkara'da bıyık durumuna göre 240, köylerde 415 kişinin tarifi yapılmıştır. Malkara merkezindeki nüfusun \%25.83'ü kumral bıyıklı, \%23.33'ü sarı bıyıkl1, \%22.5'i ter bıyıklı, \%17.08'i şâbb-1 emred, $\% 11.25$ 'i ise kara bıyıklıdır. Köylerindeki oransal dağılım ise şu şekildedir: \%29.63 sarı bıyıklı, \%23.61 şâbb-1 emred, \%22.89 ter bıyıklı, \%19.27 kumral bıyıklı, \%4.57 ise kara biyıklıdır.

Şâbb-1 emred ve ter bıyıklı ifadeleri daha genç yaştaki nüfusu tanımlamak için kullanılmıştır. Bu iki ifade kırsal kesimdeki nüfusu tanımlamak için daha fazla kullanılmış olup bıyık tarifine göre kaydedilmiş şahıslara göre kırsal kesimdeki nüfusun daha genç olduğunu söyleyebiliriz.

\footnotetext{
${ }^{51}$ Daha sakalı bıyığı gelmemiş delikanlı. Bkz. Şemseddin Sami, age., s.596.
} 
Burçin IŞIM

Tablo 8: Malkara ve Köylerindeki İskân Edenlerin Bıyık Durumuna Göre Tasnifi

\begin{tabular}{|c|c|c|c|c|c|}
\hline Yer & Şâbb-ı emred & Ter bıyıkı & Kara bıyıkı & Kumral bıyıkı & $\begin{array}{c}\text { Sarı } \\
\text { bıyıklı }\end{array}$ \\
\hline $\begin{array}{c}\text { Malkara } \\
\text { Merkezi }\end{array}$ & 41 & 54 & 27 & 62 & 56 \\
\hline $\begin{array}{c}\text { Malkara } \\
\text { Köyleri }\end{array}$ & 98 & 95 & 19 & 80 & 123 \\
\hline
\end{tabular}

Yukarıda belirttiğimiz gibi boy durumundan sonra sakal ya da bıyıkları ile kişilerin tarifi yapılmıştır. Sakal ile tarif edilen kişiler, müzellef, kara, kumral, sarı, kırçıl, kırca, kır, ve ak sakallı olmak üzere toplam sekiz ayrı biçimde deftere kaydedilmiștir. Malkara'da 51 kiși ile kır sakallılar zirvede yer alırken, köylerinde ise 66 kişi ile kumral sakallı tarifini en önde görmekteyiz. 425 kişi sakal durumuna göre tanımlanmış olup bunun 195'i Malkara'da, 230'u ise köylerdedir. Hem merkezde hem köylerinde kumral, kır ve ak sakallı tariflerinin ilk üç sırada yer aldığını görmekteyiz. Üç sırada yer alan bu ifadelerin yüzdelik oranı Malkara'da \%26.15 ile kır sakallılar, \%22.01 ile kumral sakallılar ve \%18.97 ile ak sakallılar olarak oluşmuştur. Köylerde ise \%28.69 ile kumral sakallılar, \%19.56 ile kır sakallılar ve \%16.52 ile ak sakallılar olarak sıralanmıştır.

Tablo 9: Malkara ve Köylerinde İskân Edenlerin Sakal Durumuna Göre Tasnifi

\begin{tabular}{|c|c|c|c|c|c|c|c|c|}
\hline Yer & $\begin{array}{c}\text { Müzellef } \\
\text { sakallı }\end{array}$ & $\begin{array}{c}\text { Kara } \\
\text { sakallı }\end{array}$ & $\begin{array}{c}\text { Kumral } \\
\text { sakallı }\end{array}$ & $\begin{array}{c}\text { Sarı } \\
\text { sakalı }\end{array}$ & $\begin{array}{c}\text { Kırçıl } \\
\text { sakallı }\end{array}$ & $\begin{array}{c}\text { Kırca } \\
\text { sakallı }\end{array}$ & $\begin{array}{c}\text { Kır } \\
\text { sakalı }\end{array}$ & $\begin{array}{c}\text { Ak } \\
\text { sakallı }\end{array}$ \\
\hline $\begin{array}{c}\text { Malkara } \\
\text { Merkezi }\end{array}$ & 3 & 22 & 43 & 17 & 6 & 16 & 51 & 37 \\
\hline $\begin{array}{c}\text { Malkara } \\
\text { Köyleri }\end{array}$ & 1 & 16 & 66 & 22 & 28 & 14 & 45 & 38 \\
\hline
\end{tabular}

Sonuç

Nüfus defterleri araştırmacılar için, özellikle yerel tarih araştırmacıları için, bünyesinde barındırdığı eşsiz bilgiler açısından oldukça kıymetlidir. Nüfus defterlerinde kaza, köy, çiftliklerin idari durumları, ve taksimatları kazalar ve köylerdeki imamlar, muhtarlar, şahısların adları, kaydedilen şahısların yaşları, fiziki özellikleri, baba adları, özürlülük durumları, gurbette olanların nerede oldukları ve ne amaçla gittikleri belirtilmiştir.

$\mathrm{Bu}$ makaleye konu olan, "Malkara Müslim Nüfus Defteri", Başbakanlık Osmanlı Arşivinde, NFS. d. Koduyla, 4114 numarada kayıtlıdır. Kaynağımız olan bu nüfus defterinde sadece nüfus sayısı ile ilgili bilgiler verilmemektedir. İncelediğimiz defterde, Malkara kazası Müslüman erkek nüfusu, sayı, isim, yaş, meslekleri ve fiziki özellikleri ile birlikte tespit edilmiştir. $\mathrm{Bu}$ tespitler neticesinde bütün veriler ayrı başlıklar altında toplanarak tablolar halinde gösterilmeye çalışılmıştır.

Araştırmamız göstermiştir ki, Malkara'da 27 mahalle, 29 köy ve 14 Çiftlik vardır. Toplam Müslüman erkek nüfus 1.684'tür. Malkara ve köylerinde tespit edilen mesleklere göre halkın büyük çoğunluğu çiftçilikle uğraşıyordu. Bununla birlikte Debbağ olarak kayıt edilen kişilerin sayısı da oldukça fazlaydı.

İncelediğimiz defterde şahıslarla ilgili bir çok askerî bilgi mevcuttur. Kişilerin nerede, ne zaman, hangi sınıfta yada alanda askerlik yaptığını belirtilen bir çok kayıt vardır. Buna 
kayıtlara göre, askerlik yükümlülüklerini yerine getirenlerin çoğu bahriyeli idi. Hatta nüfus defterinin tutulduğu sene olan 1845 yılında askere gidenlerin tamamı bu sinıfa mensup görevli askerdi.

Nüfus sayımı askerliğe elverişli potansiyel erkek Müslüman nüfusun durumunu tespit etmek ve bu tespitlerin sonucunda devlet yöneticilerinin askerî alanda plan yapmalarını kolaylaştırmak amacına yönelik yapıldı̆̆ından defterlerin içerisinde sadece erkek nüfus yazılmış, kadınlar ve kızlar kayıt dışı bırakılmıştır.

\section{KAYNAKÇA}

(BOA) Başbakanlık Osmanlı Arşivi, Malkara Nüfus Defteri, Nr. 4114.

(BOA) Başbakanlık Osmanlı Arşivi, Keşan Nüfus Defteri, Nr. 4096.

AKYEL, Salih-Kamil ÖZDEMIR, "1835 Tarihli Nüfus Defterine Göre Tirebolu'da Gayrimüslim Nüfus Yapısı”, Türkiyat Araştırmaları Dergisi, S.37, s.163-179.

ARTUNAY, Mehmet-Ali LAFÇI, Osmanlı Arşiv Belgelerinde Zara II Zara/Koçgiri Nüfus Defterleri, Kitabevi Yayınevi, İstanbul 2013.

BOZKURT, Nebi, "Nüfus", Türkiye Diyanet Vakfi İslâm Ansiklopedisi, C.33, Ankara 2007, s. 293-294.

ÇADIRCI, Musa, "1830 Genel Sayımına Göre Ankara Şehir Merkezi Nüfusu Üzerinde Bir Araştırma", Osmanlı Araştırmaları I, İstanbul 1980, s. 109-132.

DEMIRCİ, Süleyman-Kâzım KARTAL, "Osmanlı Nüfus Defterleri'nin Tarih Yazımındaki Yeri: 1835 Tarihli Trabzon Vilayeti Maçuka/MAÇKA Kazası Müslim Nüfus Defteri Örneği”, History Studies International Journal Of History, Volume 6, Issue 3, April 2014, s. 119-145.

DEVELIOĞLU, Ferit, Osmanlıca-Türkçe Ansiklopedik Sözlük, Aydın Kitabevi Yayınları, Ankara 1993.

İPEK, Nedim-Rıza KARAGÖZ-Cihat USLUCAN, Canik Sancağı Samsun Kazası'nın Nüfus Yapısı (1834-1845) Canik Belediyesi Kültür Yayınlar1, Kültür Yayınları No: 9, Samsun 2016.

KANDEMİ, Adem-Fikri OKUT, Osmanlıca Türkçe Sözlük, Erdem Yayınları, İstanbul 1997.

KARPAT, Kemal H., Osmanl Nüfusu (1830-1914) Demografik ve Sosyal Özellikleri, Tarih Vakfı Yurt Yayınları, İstanbul 2003.

Osmanlı İdaresi'nde Kıbrıs, (Nüfusu-Arazi Dağılımı ve Türk Vakıfları), T.C. Başbakanlık Devlet Arşivleri Genel Müdürlüğü Osmanlı Arşivi Daire Başkanlığı, Yayın No: 43, Ankara 2000.

ÖZ, Mehmet, "Tahrir" Türkiye Diyanet Vakfi İslâm Ansiklopedisi, C.39, Ankara 2007, s. 425-429.

ÖZER, Hümeyra, Lâdik Nüfus Defteri (1846 Tarihli) Transkripsiyon ve Değerlendirme, T. C. İstanbul Üniversitesi Sosyal Bilimler Enstitüsü, basılmamış yüksek lisans tezi, İstanbul 2015. 
SERBESTOĞLU, İbrahim, “19. Yüzyılda Osmanlı Devleti’nde Nüfus Algısının Değişimi ve Nüfusu Arttırma Çabasında Müfettişlerin Rolü”, Balıkesir Üniversitesi Sosyal Bilimler Enstitüsü Dergisi, 17/31, Haziran 2014, s.255-273.

SEZGİN, İbrahim, "Malkara Şehri (1475-1601)", İlmî Araştırmalar II, İstanbul 1996, s.119-130.

ŞAŞMAZ, Musa (1995), "The Ottoman Censuses And The Registration Systems in The Nineteenth and Early Twentieth Centuries", Ankara Üniversitesi Osmanlı Tarihi Araştırma ve Uygulama Merkezi Dergisi, S: 6 s. 289-305.

ŞEKER, Mehmet-Nilgün ÇEVIK, Denizli-1831 Nüfus Sayımı Prosopografisi, İzmir 2007.

Şemseddin Sami, Kamûs-ı Turkî, (Latin Harfleriyle), Haz: Raşit GÜNDOĞDU, Niyazi ADIGÜZEL, Ebul Faruk ÖNAL, İdeal Kültür, İstanbul 2012.

TEKİN, Zeki, "Türklerde Dericilik", Türkiye Diyanet Vakfi İslâm Ansiklopedisi, C.39, Ankara 2017, s.174-175. 